\title{
Present and future water resources in India: Insights from satellite remote sensing and a dynamic global vegetation model
}

\author{
S J MURRAY \\ School of Earth Sciences, Wills Memorial Building, University of Bristol, Queens Road, Bristol, BS8 1RJ, UK. \\ e-mail: steve.murray@bristol.ac.uk
}

India is a country of particular interest with regard to its future water resources, as it is expected to undergo continued rapid population growth while also being especially sensitive to climate change. The Land-surface Processes and eXchanges Dynamic Global Vegetation Model (LPX-DGVM) is used here to simulate present and future runoff in India using ClimGen pattern-scaled scenarios of $1^{\circ}, 2^{\circ}$ and $4^{\circ} \mathrm{C}$ temperature increase (scaled to 2050) forced by six general circulation models (GCMs). As is the case with many DGVMs, groundwater storage is not simulated by LPX, so in order to form a more comprehensive understanding of water resources, Gravity Recovery and Climate Experiment (GRACE) satellite estimates for north-west India are incorporated into this study and compared to LPX runoff simulations. Runoff is simulated to have increased slightly $(1.5 \mathrm{~mm} /$ year $)$ in this region during 2002-2006, while groundwater extractions appear to have been made at rates of $40 \pm 10 \mathrm{~mm} /$ year.

North-west India is simulated to experience considerable increases in runoff by 2070-2099, with a mean change of $189 \mathrm{~mm} /$ year for $2^{\circ} \mathrm{C}$ climate change (although the range of model results, $247 \mathrm{~mm} /$ year, demonstrates high uncertainty among GCMs). Precipitation is shown to have an important bearing on runoff generation, while the degree of warming is shown to affect the magnitude of future runoff. This may subsequently influence the longevity of the local groundwater resource. However, at recent rates of depletion and in view of expected population growth, the long-term sustainability of groundwater reserves in north-west India is in doubt.

\section{Introduction}

The present and future status of water resources in many regions is closely monitored due to the pressures of climate, land cover and population change (Murray et al. 2012). Freshwater availability and consumption is of particular interest in India due to the country supporting an increasingly large population with decreasing per capita water supplies (Mall et al. 2006). Climate change offers the potential to significantly alter precipitation and surface water regimes in India (e.g., Chattopadhyay and Hulme 1997; Kumar et al. 2005), while the anticipated population increase and expanding economy is expected to exacerbate stress on groundwater reserves (e.g., Amarasinghe et al. 2007; Jain et al. 2007). As the region is among both the most intensively irrigated and densely populated in the world (Kumar et al. 2005), it is critical that water security is ensured in order to

Keywords. Water resources; hydrology; climate change; remote sensing; Gravity Recovery and Climate Experiment (GRACE); dynamic global vegetation model; Land-surface Processes and eXchanges (LPX); Lund-Potsdam-Jena (LPJ); groundwater depletion; droughts; population change. 
prevent the socio-economic adversities associated with water resource shortages. Of particular concern is north-west India, which is populated by $\sim 114,000,000$ people and identified by the Indian Ministry of Water Resources (2006) as a region where groundwater extractions exceed recharge.
Recent hydrological research regarding northwest India has largely focused on optimizing agricultural yields against the backdrop of increasing water stress. Jalota and Arora (2002) used a simple hydro-agricultural model to estimate variability in evaporation and drainage losses under a variety

Table 1. ClimGen-prescribed mean temperature increase scenarios for each GCM, relative to 1961-1990.

\begin{tabular}{|c|c|c|c|c|}
\hline GCM & Reference & $\begin{array}{c}\text { Mean global } \\
\text { temperature } \\
\text { increase at } 2050\end{array}$ & $\begin{array}{c}\text { Mean temperature } \\
\text { increase for } \\
\text { India, 2070-2099 }\end{array}$ & $\begin{array}{c}\text { Mean temperature } \\
\text { increase for north-west } \\
\text { India, } 2070-2099\end{array}$ \\
\hline CCCma CGCM3 & Flato et al. (2000) & \multirow{5}{*}{$2^{\circ} \mathrm{C}$} & $4.0^{\circ} \mathrm{C}$ & $4.4^{\circ} \mathrm{C}$ \\
\hline CSIRO MK3.0 & Gordon et al. (2002) & & $4.1^{\circ} \mathrm{C}$ & $4.3^{\circ} \mathrm{C}$ \\
\hline IPSL CM4 & Marti et al. (2005) & & $4.2^{\circ} \mathrm{C}$ & $4.4^{\circ} \mathrm{C}$ \\
\hline MPI ECHAM5 & Roeckner et al. (2003) & & $4.3^{\circ} \mathrm{C}$ & $4.7^{\circ} \mathrm{C}$ \\
\hline \multirow[t]{2}{*}{ NCAR CCSM3.0 } & Kiehl et al. (1998) & & $3.2^{\circ} \mathrm{C}$ & $3.4^{\circ} \mathrm{C}$ \\
\hline & & $\int 1^{\circ} \mathrm{C}$ & $1.7^{\circ} \mathrm{C}$ & $1.6^{\circ} \mathrm{C}$ \\
\hline \multirow[t]{2}{*}{ UKMO HadCM3 } & Gordon et al. (2000) & $2^{\circ} \mathrm{C}$ & $3.9^{\circ} \mathrm{C}$ & $3.7^{\circ} \mathrm{C}$ \\
\hline & & $4^{\circ} \mathrm{C}$ & $8.3^{\circ} \mathrm{C}$ & $8.0^{\circ} \mathrm{C}$ \\
\hline $\begin{array}{l}\text { Mean of six GCMs } \\
\text { for } 2^{\circ} \mathrm{C} \text { change }\end{array}$ & - & $2^{\circ} \mathrm{C}$ & $4.0^{\circ} \mathrm{C}$ & $4.1^{\circ} \mathrm{C}$ \\
\hline
\end{tabular}

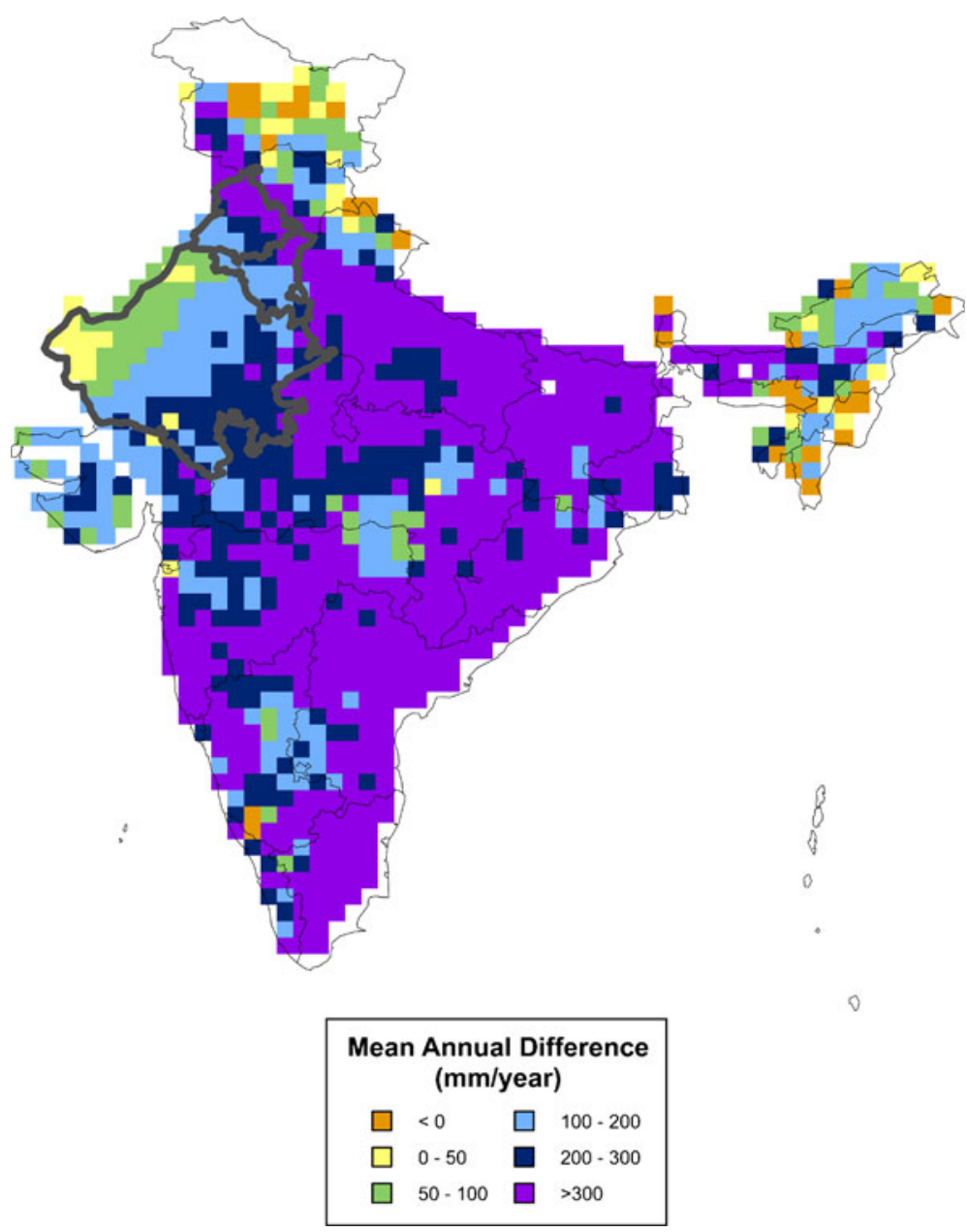

Figure 1. Absolute difference in LPX and ISLSCP II mean annual runoff (mm/year) for 1986-1995. The three states studied in this research are marked in bold. 
of cropped soils in the state of Punjab. Annual evapotranspiration was found to be $6-11 \mathrm{~cm}$ less for coarse-textured soils (compared with intermediatetextured soils), yet generally had a higher irrigation water requirement. Maize-wheat and cottonwheat cropping configurations were shown to have relatively low irrigation requirements, while evaporation losses were reduced as a result of straw mulching. Thus, this cropping approach may offer a more water-efficient alternative to the rice-wheat system for this region (Jalota and Arora 2002; see also Goyal 2004). Timsina et al. (2008) also show wheat yields in the Punjab to be highest when irrigation is applied based on soil moisture status rather than crop growth stage. These examples of agricultural water management may help reduce water stress per unit of crop yield, but a continual growth in population and food demand is likely to induce an associated net increase in irrigation, along with associated evaporation and drainage losses.

Groundwater resources in India have traditionally been assessed at the local scale through direct water table measurements (e.g., Naik and Awasthi 2003; Sharda et al. 2006), geochemical tracers (e.g., Sukhija et al. 1996; Rangarajan and Athavale 2000) and electrical resistivity techniques (e.g., Israil et al. 2006). More recently, satellite-based gravity field retrievals of terrestrial hydrology have been employed for monitoring large-scale groundwater fluxes (e.g., Yeh et al. 2006; Strassberg et al. 2009; Syed et al. 2010). India has received particular attention in this respect, due to the suitability of the Gravity Recovery and Climate Experiment (GRACE; Tapley et al. 2004) satellite mission in detecting gravity anomalies associated with large groundwater extractions (Rodell et al. 2009; Tiwari et al. 2009).

Launched in 2002, GRACE simultaneously detects global water stored at the terrestrial surface, throughout the soil column and also groundwater at coarse spatial resolution (at least several hundred kilometres) typically on a sub-monthly basis. For April 2002 to June 2008, Tiwari et al. (2009) attributed a weakening of Earth's gravity field over northern India to groundwater depletion

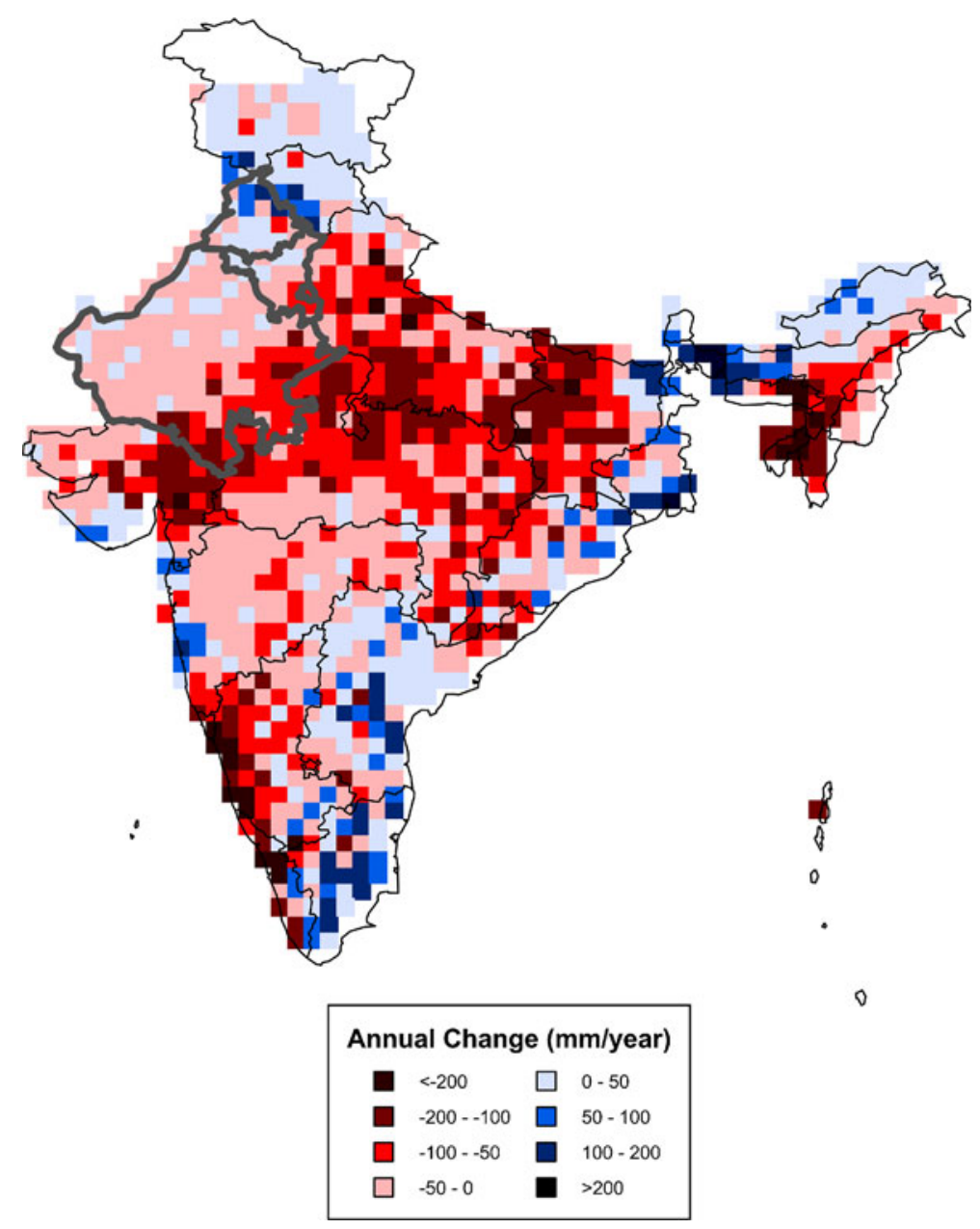

Figure 2. Absolute change (mm/year) in mean annual runoff in India between 1950-1977 and 1978-2005. 
of $54 \pm 9 \mathrm{~km}^{3} /$ year $(\sim 10 \mathrm{~cm} /$ year water table lowering), while Rodell et al. (2009) found a $17.7 \pm$ $4.5 \mathrm{~km}^{3}$ /year decrease $(4.0 \pm 1.0 \mathrm{~cm} /$ year water table lowering) for a similar region during August 2002 to October 2008. Precipitation, soil moisture, biomass, glacial ablation, lake and reservoir storage were not thought to have contributed significantly to these trends. Apart from the spatial and temporal incongruencies, discrepancies in flux volume between these two studies may have derived from the choice of land surface models used to distinguish the groundwater signal from other terrestrial water storage.

This research aims to estimate the availability of present and future water resources in India, with a focus on semi-arid north-west India, by using the Land-surface Processes and eXchanges Dynamic Global Vegetation Model (LPX-DGVM; Murray et al. 2011; Prentice et al. 2011) to simulate terrestrial runoff. Unlike most global hydrological models, DGVMs tend not to incorporate groundwater into simulations of hydrological flows, but explicitly represent micro- to macro-scale biospheric processes, which may play important roles in mediating hydrology in response to climate change (Murray et al. 2012; Gerten et al. 2004). As such, LPX-modelled runoff is compared with GRACEderived estimates of groundwater for north-west India from Rodell et al. (2009), in order to gain a holistic view of water resources. The combined assessment of surface and sub-surface water fluxes will aid quantifications of the hydrological budget for this region, and provide greater insights into the direction of runoff trends relative to the groundwater regime.

\section{Methodology}

\subsection{The LPX dynamic global vegetation model}

LPX simulates global biogeochemical and biogeophysical land surface processes through processbased representations of the biosphere via nine

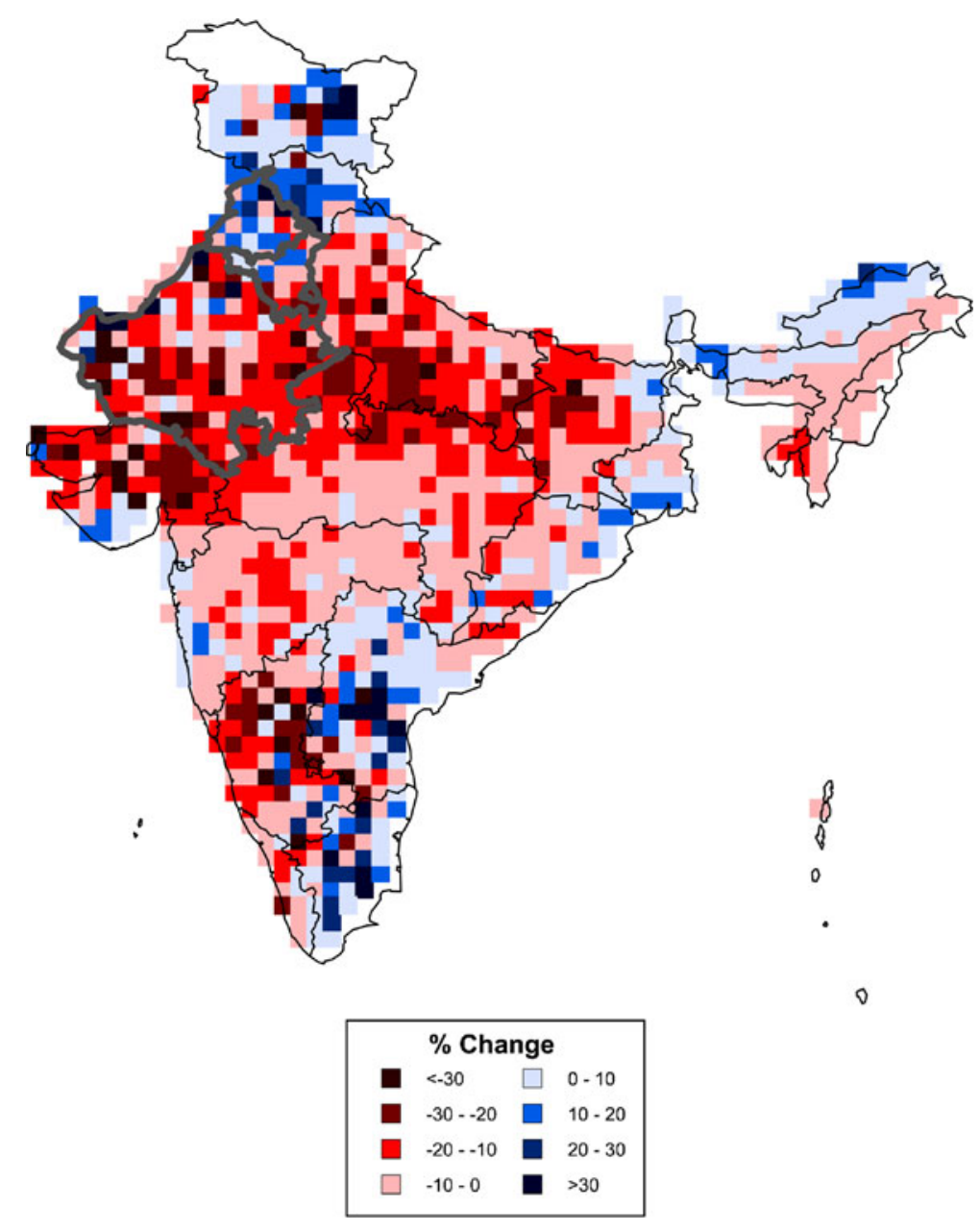

Figure 3. Relative change (\%) in mean annual runoff in India between 1950-1977 and 1978-2005. The three states studied in this research are marked in bold. 
plant functional types (PFTs; Woodward and Cramer 1996) at $0.5^{\circ}$ spatial resolution. Global and catchment scale hydrology has been previously evaluated and shows LPX to produce reasonable estimates of runoff on an interannual and seasonal basis (Gerten et al. 2004; Murray et al. 2011; Ukkola and Murray 2013). Slight overestimates in interannual runoff are simulated for 20th century runoff in north-west India after accounting for withdrawals, but the timings of peak runoff are found to be simulated well (Murray et al. 2011; see also section 3.1). In addition, LPX and the LundPotsdam-Jena (LPJ) root model have been extensively documented and evaluated for biospheric processes and carbon cycling (Sitch et al. 2003; Hickler et al. 2006), wildfires (Prentice et al. 2011) and soil moisture (Wagner et al. 2003). LPX hydrological evaluation and processes are detailed by Gerten et al. (2004) and Murray et al. (2011), and thus only the processes relevant to runoff generation are overviewed here.

Simulated runoff is determined from net precipitation (after interception) minus transpiration from two soil layers, and evaporation from the upper soil layer (Gerten et al. 2004). Interception is a function of precipitation, PFT, leaf area index, leaf phenology and vegetative fractional grid cell cover (Murray 2013). Soil moisture is calculated daily as the residual of evaporation, transpiration, infiltration and runoff. The Priestley-Taylor method is used to derive potential evaporation (Priestley and Taylor 1972; Hobbins et al. 2001) while a soil--vegetation moisture supply term and the lower bound of an atmospheric demand parameter are used to calculate transpiration (Monteith 1995). River routing is not incorporated into LPX, so runoff is assumed to reach the basin outlet at the end of each model day.

\subsection{Model set-up, data input, evaluation and future scenarios}

LPX was initialized using the lowess technique (Cleveland 1979) to detrend the model input variables. In order to attain stability among slow carbon

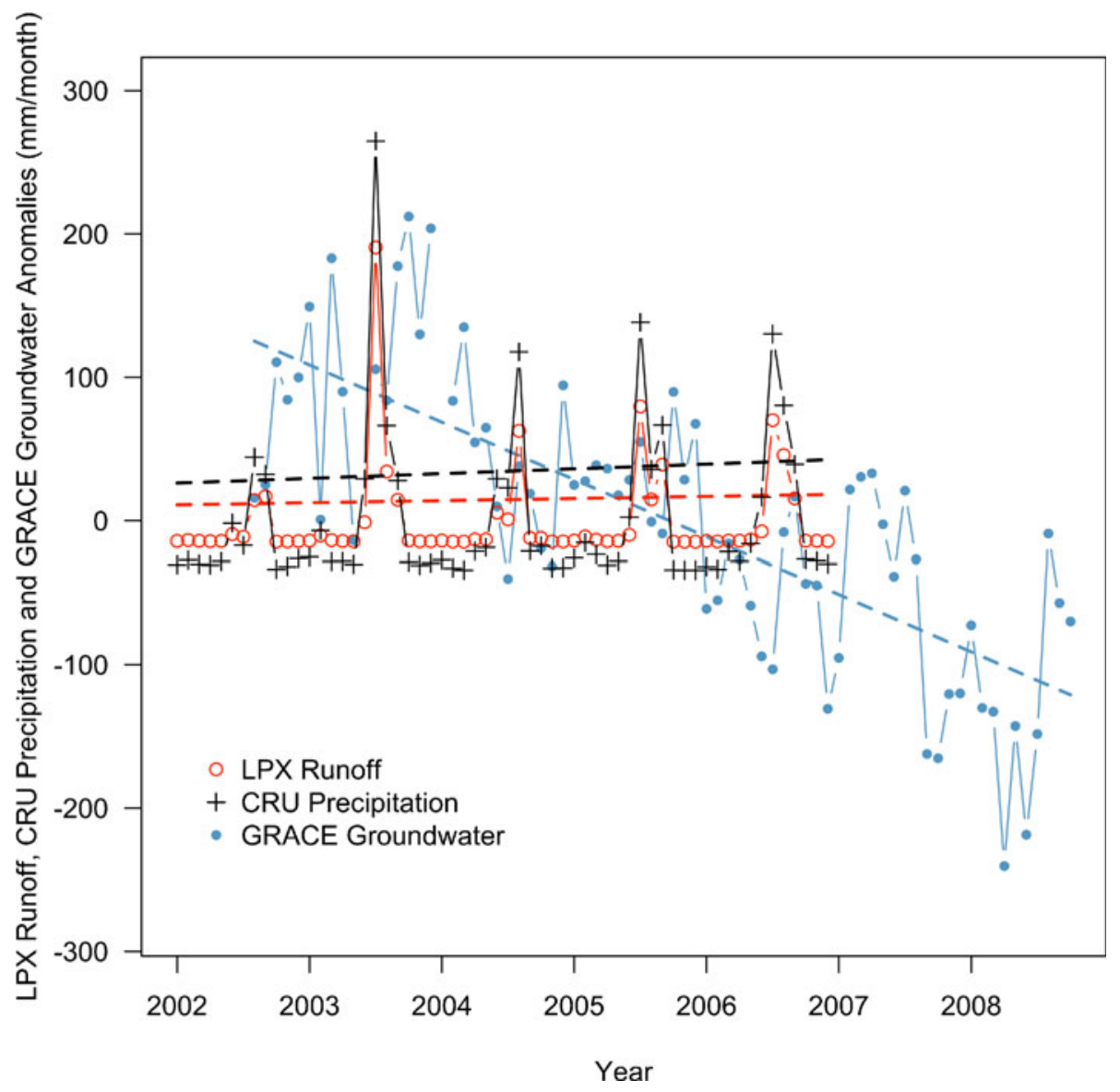

Figure 4. Mean monthly LPX runoff, CRU precipitation (mm/month; January 2002 to December 2006) and GRACE groundwater retrieval (mm/month; August 2002 to October 2008) anomalies from Rodell et al. (2009) averaged across Haryana, Punjab and Rajasthan. 
stores, the 1948-2000 period was recycled at 286 ppm $\mathrm{CO}_{2}$ with $1850 \mathrm{HYDE}$ croplands (Klein Goldewijk et al. 2007) until the 50 year means of each grid cell varied by $<2 \%$. LPX is forced for 1850-2006 using Climate Research Unit TS 3.0 (Mitchell and Jones 2005) monthly means of air temperature, precipitation, wet day frequency and cloud cover fraction (all detrended prior to 1901), global annual $\mathrm{CO}_{2}$ concentrations (Etheridge et al. 1996; IPCC 2001) and nine fixed soil texture classes (Zobler 1986) (see Murray et al. 2011 for further details).

LPX global simulation outputs have been a subset to represent the land area covered by the northwest Indian states of Haryana (including Delhi), Punjab and Rajasthan and thus form a coincident spatial domain with that of Rodell et al. (2009). This subsetting approach has been shown to be effective at the small catchment scale by Ukkola and Murray (2013) using LPX, and as such, statistical downscaling is not performed.

Simulations of LPX runoff are evaluated against International Satellite Land-Surface Climatology
Project Initiative II (ISLSCP II) gridded runoff data from the University of New HampshireGlobal Runoff Data Centre (UNH-GRDC) (Fekete et al. 1999, 2002; see Murray et al. 2011). These data are formed from a combination of climatedriven water balance runoff model (WBM) outputs and GRDC-observed river discharge observations for the period 1986-1995, on a monthly basis at $0.5^{\circ}$ resolution. Gauging station locations are shown in Fekete et al. (1999). ISLSCP II data are summed to form annual means and subsetted to be congruent with LPX grid cells covering India.

Runoff is projected for 2070-2099 based on the ClimGen pattern-scaled scenarios of climate change (http://www.cru.uea.ac.uk/ timo/ climgen/; Mitchell and Osborn 2005; Murray et al. 2012) and using an ensemble of general circulation models (GCMs) to force LPX. Six GCMs were used to simulate runoff change for a global mean 'critical' temperature increase of $2^{\circ} \mathrm{C}$ (scaled to 2050, relative to 1961-1990). This equates to a simulated mean temperature change of $4.0^{\circ} \mathrm{C}$ for India and $4.1^{\circ} \mathrm{C}$ for north-west India by $2071-2099$
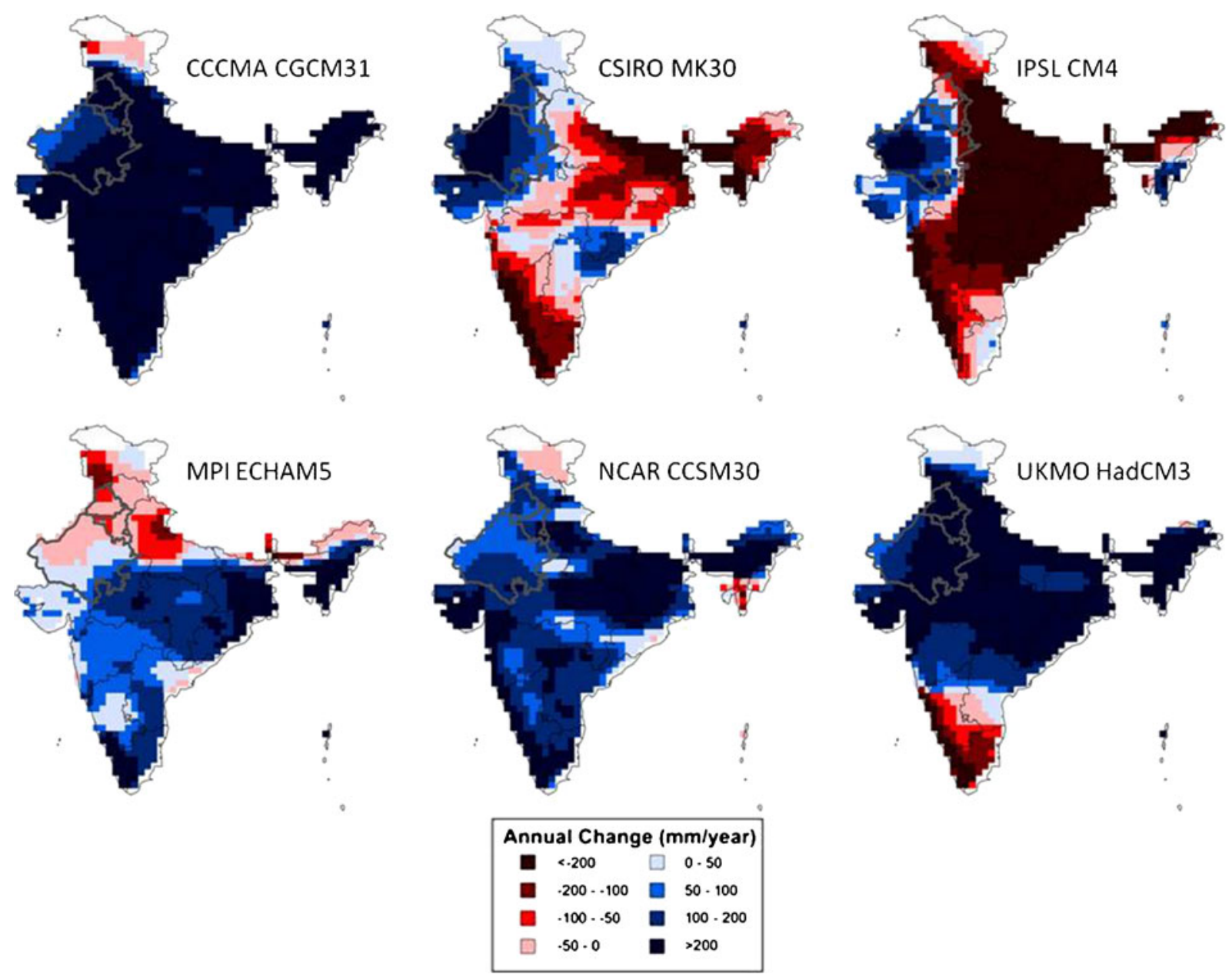

Figure 5. LPX absolute change in 1961-1990 to 2070-2099 runoff in India forced via six GCMs for $2^{\circ} \mathrm{C}$ (scaled to 2050 ) mean global climate change. 
(table 1). Similarly, the UKMO HadCM3 GCM is used to generate runoff projections for $1^{\circ}, 2^{\circ}$ and $4^{\circ} \mathrm{C}$ global mean climate change (scaled to 2050; simulated temperature increases for India are shown in table 1 ).

\subsection{GRACE groundwater retrievals}

Since GRACE provides estimates of total terrestrial water storage anomalies, the groundwater component is typically inferred through either local observations (e.g., Yeh et al. 2006) or subtracting modelled land surface and soil hydrology (e.g., Tiwari et al. 2009). Rodell et al. (2009) averaged five simulations of GLDAS (Global Land Data Assimilation System; Rodell et al. 2004) based on three land surface models and three meteorological datasets, to isolate change in groundwater storage across the three aforementioned states in north-west India.

Groundwater storage anomalies for the region were determined by Rodell et al. (2009) for August 2002 to October 2008. Gravity products provided by the Center for Space Research at the University of Texas were employed, and composed of Stokes coefficients truncated to a maximum 60 degrees.
These were subsequently filtered using the method of Swenson and Wahr (2006) to increase the signalto-noise ratio and spatially smoothed via an averaging kernel applied to the Stokes coefficients, in order to establish groundwater time-series anomalies (see Rodell et al. 2009 for further details).

\section{Results and discussion}

\subsection{Evaluation of LPX simulated runoff}

LPX overestimates runoff throughout most of India (by typically $>300 \mathrm{~mm} /$ year cf. ISLSCP II), but less so in the north-west of the country, where runoff in the majority of the region is overestimated by $0-200 \mathrm{~mm} /$ year (figure 1). The two datasets used for this evaluation are highly correlated $\left(r^{2}=0.91 ; p \approx 0\right)$ and demonstrate systematic model bias. Thus, the subsequent analysis is justified as it focuses on trends (with consideration of input uncertainties) in the region of India most successfully evaluated.

\subsection{Change in 1950-2005 runoff for India}

Change in mean annual runoff is simulated for India between 1950-1977 and 1978-2005, in order
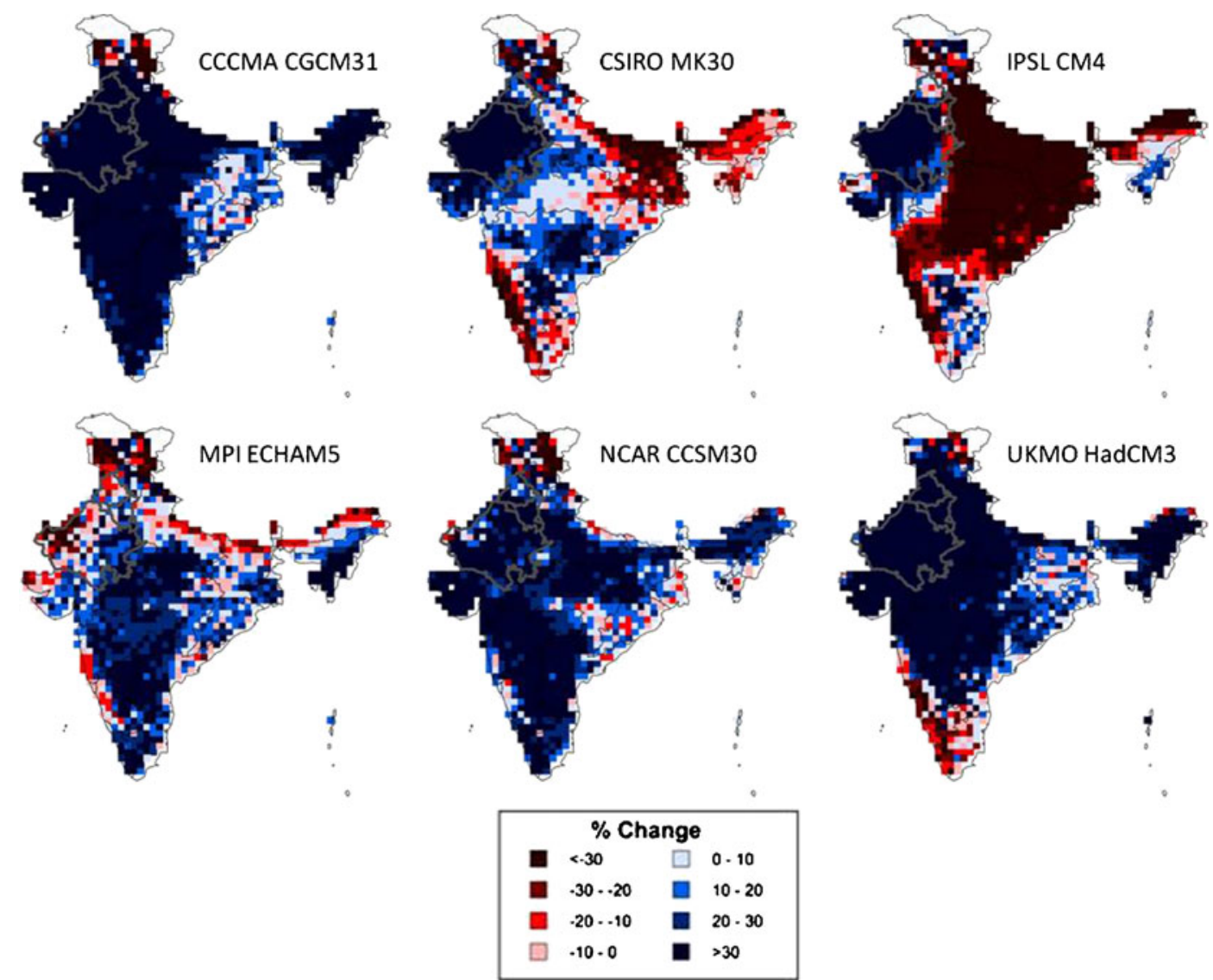

Figure 6. LPX relative change in 1961-1990 to 2070-2099 runoff in India forced via six GCMs for $2^{\circ} \mathrm{C}$ climate change (scaled to 2050). 
to provide a context for subsequent analysis at a more local scale and for a shorter timespan. Results show a considerable area of high runoff decreases through the north-central region of the country, which range between -60 and $-180 \mathrm{~mm} /$ year $(-15$ to $-30 \%$ ) (figures 2,3$)$. Much of this area also coincides with that identified by Tiwari et al. (2009) and Wada et al. (2010) as having undergone significant recent depletions in groundwater supplies.

The three states under focus in this study show disparate trends in runoff directions. Much of Rajasthan and Haryana are typified by decreases of $>-50 \mathrm{~mm} /$ year $(-1$ to $-15 \%)$, but show many more significant reductions (up to $-160 \mathrm{~mm} /$ year; $-31 \%$ ) in the south-east regions. In contrast, Punjab generally shows increases which vary between 5 and $145 \mathrm{~mm} /$ year (7-34\%), which is coincidental with groundwater extractions in excess of $300 \mathrm{~mm} /$ year as demonstrated by Wada et al. (2010). So, despite the relatively large increases in mean annual runoff for this region, the current rates of extractions are still at an apparently unsustainable rate.

\subsection{Recent runoff and groundwater extraction trends in north-west India}

LPX runoff shows a slight increasing trend (within error) of $1.5 \mathrm{~mm}$ /year during 2002-2006, while precipitation increases by $3.3 \mathrm{~mm} /$ year (figure 4 ). In contrast, GRACE groundwater storage has been shown by Rodell et al. (2009) to decrease on average by $40.0 \pm 10 \mathrm{~mm} /$ year between 2002 and 2008 and in this study by $41.1 \pm 10 \mathrm{~mm} /$ year between 2002 and 2006. These seemingly opposing trend directions would appear to add weight to the theory of water consumption driving groundwater depletion in north-west India (Rodell et al. 2009).

Groundwater fluxes in the region are sensitive to the annual peak in precipitation, but also continue to show high variability when precipitation is low (figure 4). Peak rainfall coincides with an increase in groundwater in all coincident years of data, except for 2006 where a one-month delay is evident. A secondary peak in groundwater is shown $\sim 3$ months after each annual precipitation maximum, which may reflect slower (subsurface) flow to groundwater reservoirs.
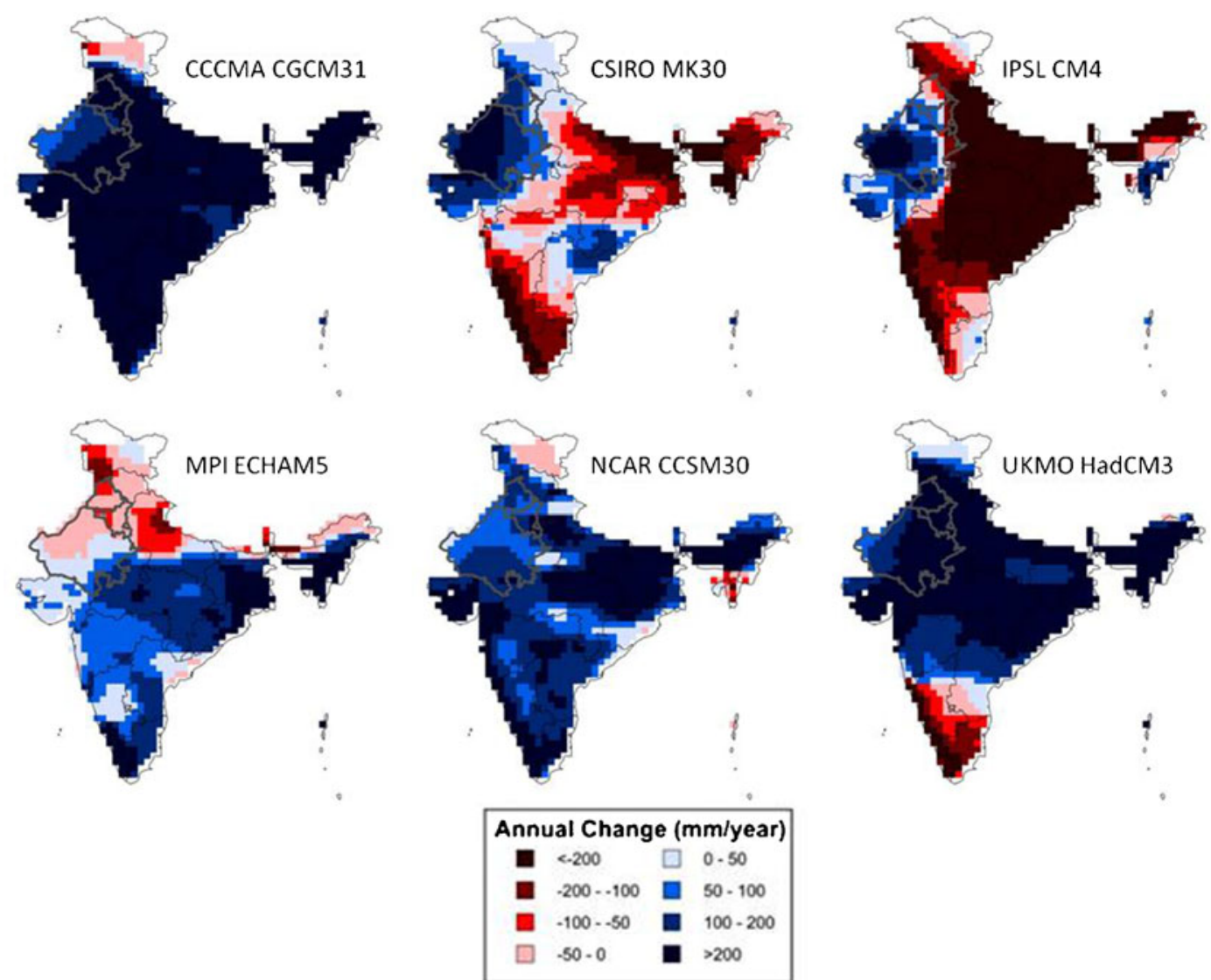

Figure 7. Change in 1961-1990 to 2070-2099 mean annual precipitation for $2^{\circ} \mathrm{C}$ (scaled to 2050) mean global climate change, using six GCMs. 


\subsection{Future runoff and precipitation in India under $2^{\circ} \mathrm{C}$ climate change}

All GCMs, except IPSL CM4, show that runoff will increase throughout much of India by 2070 2099 (figures 5 and 6 ) under $2^{\circ} \mathrm{C}$ climate change, although the extent of change varies substantially between models (typically between 10 and $400 \mathrm{~mm} /$ year; $5 \%$ and $75 \%$ ). These projected changes in runoff for India appear to be mostly driven by precipitation, as shown by their high degree of spatial correlation $\left(r^{2}=0.64 ; p \approx 0\right.$; figure $5 \mathrm{cf}$. figures 7,8$)$. Uncertainty in precipitation direction and magnitude among the GCMs also appear to determine the variability in runoff simulations. CSIRO MK30, IPSL CM4 and to a lesser degree, MPI ECHAM5, simulate runoff decreases in eastern India, but again, these vary in spatial extent and magnitude. The GCMs show a general consensus in the direction of change for the north-west region (although slight decreases are shown in the western region by MPI ECHAM5) and much closer agreement in terms of the intraregional relative distributions of runoff. It is clear however, that according to these simulations, the north-west represents among the largest increases in future runoff throughout the country at $2^{\circ} \mathrm{C}$ warming.

Using the UKMO HadCM3 GCM to simulate temperature increase of $1^{\circ}, 2^{\circ}$ and $4^{\circ} \mathrm{C}$, the direction of runoff change is shown to remain largely constant with increasing temperature, while the magnitude of change is simulated to intensify (figure 9). The main exception to this is in eastern India, where decreases of $20-200 \mathrm{~mm} /$ year $(-5$ to $-30 \%)$ for $1^{\circ} \mathrm{C}$ climate change are simulated as change of -200 to $+30 \mathrm{~mm} /$ year $(-30$ to $+20 \%)$ for $2^{\circ} \mathrm{C}$ and $>200 \mathrm{~mm} /$ year $(>30 \%)$ under $4^{\circ} \mathrm{C}$ climate change. These simulations also show runoff to decrease in southern India as temperatures rise, while north-west India shows increasing runoff.

\subsection{Future runoff in north-west India under $2^{\circ} \mathrm{C}$ global mean climate change}

All the GCMs used to simulate $2^{\circ} \mathrm{C}$ climate change show a mean increase in runoff across the three states under study (figure 10; mean change of $189 \mathrm{~mm} /$ year). However, there is a range of $247 \mathrm{~mm} /$ year in the estimate of mean future runoff among the models, which is larger than the mean differences between the temperature scenarios (112 mm/year; table 2). The changes in runoff for this region are also shown to be largely driven by changes in precipitation $\left(r^{2}=0.56 ; p \approx 0\right.$; figures $5,7,8)$ as for much of the rest of the country.

Rising temperatures are simulated to cause large increases in mean annual runoff in north-west
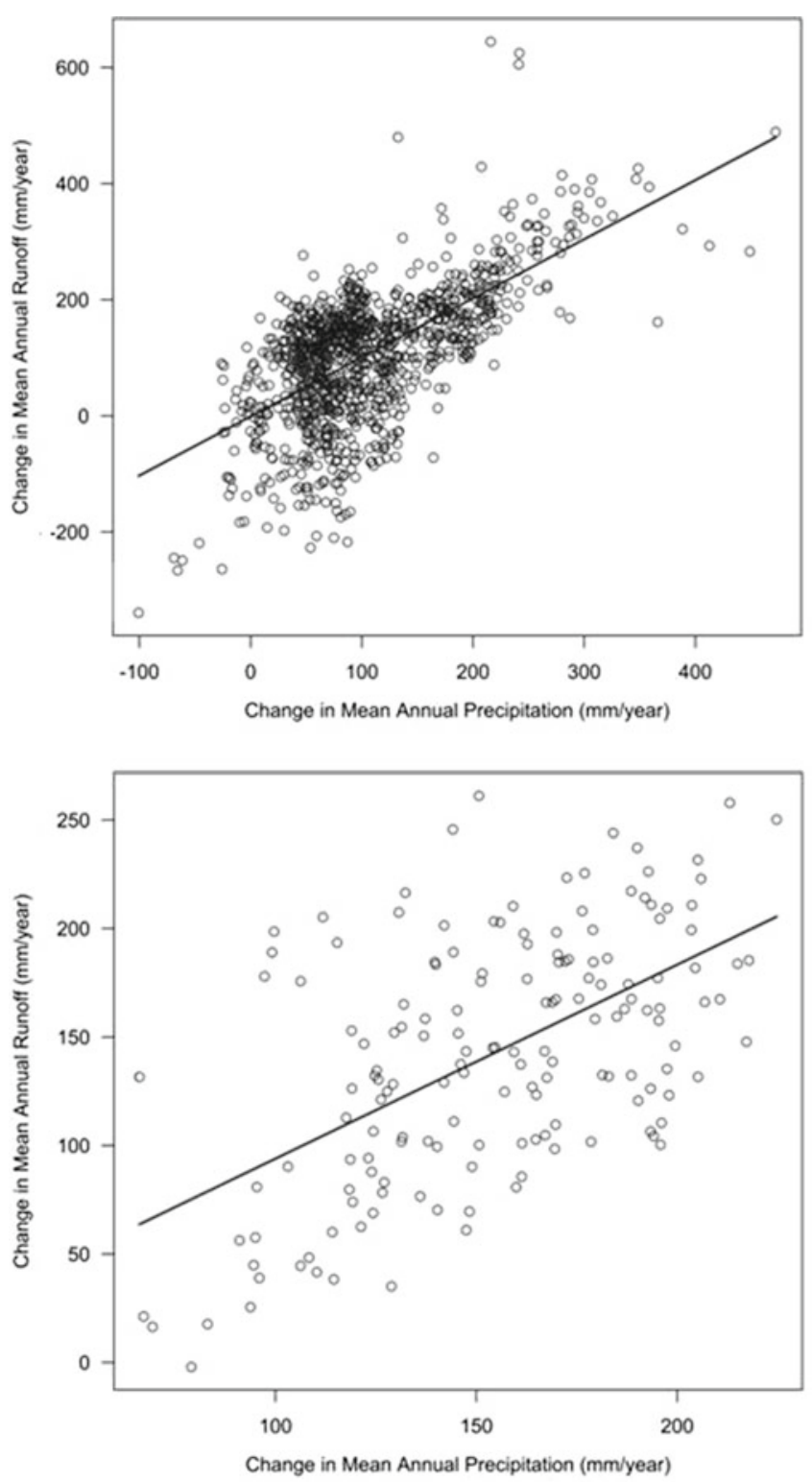

Figure 8. Correlation between 1961-1990 and 2070-2099 change in India (upper; $r^{2}=0.64 ; p \approx 0$ ) and north-west India (lower; $r^{2}=0.56 ; p \approx 0$ ) mean annual precipitation versus change in runoff on a cell-by-cell basis, for $2^{\circ} \mathrm{C}$ (scaled to 2050) mean global climate change using an ensemble mean of six GCMs.

India which may moderately extend the potential longevity of the groundwater resource (table 2). However, it should be acknowledged that the finite nature of groundwater stores (both in terms of their capacity and exhaustion) may deem the values in table 2 to be under- or overestimates. Also, while a constant rate of extraction is assumed in this study, the need for this rate to be sustained may be negated under increasing runoff, which in turn may stimulate efforts to increase surface storage measures. That said, the future local water balance may be pressured further by the likelihood of a growing population and increasingly seasonal 


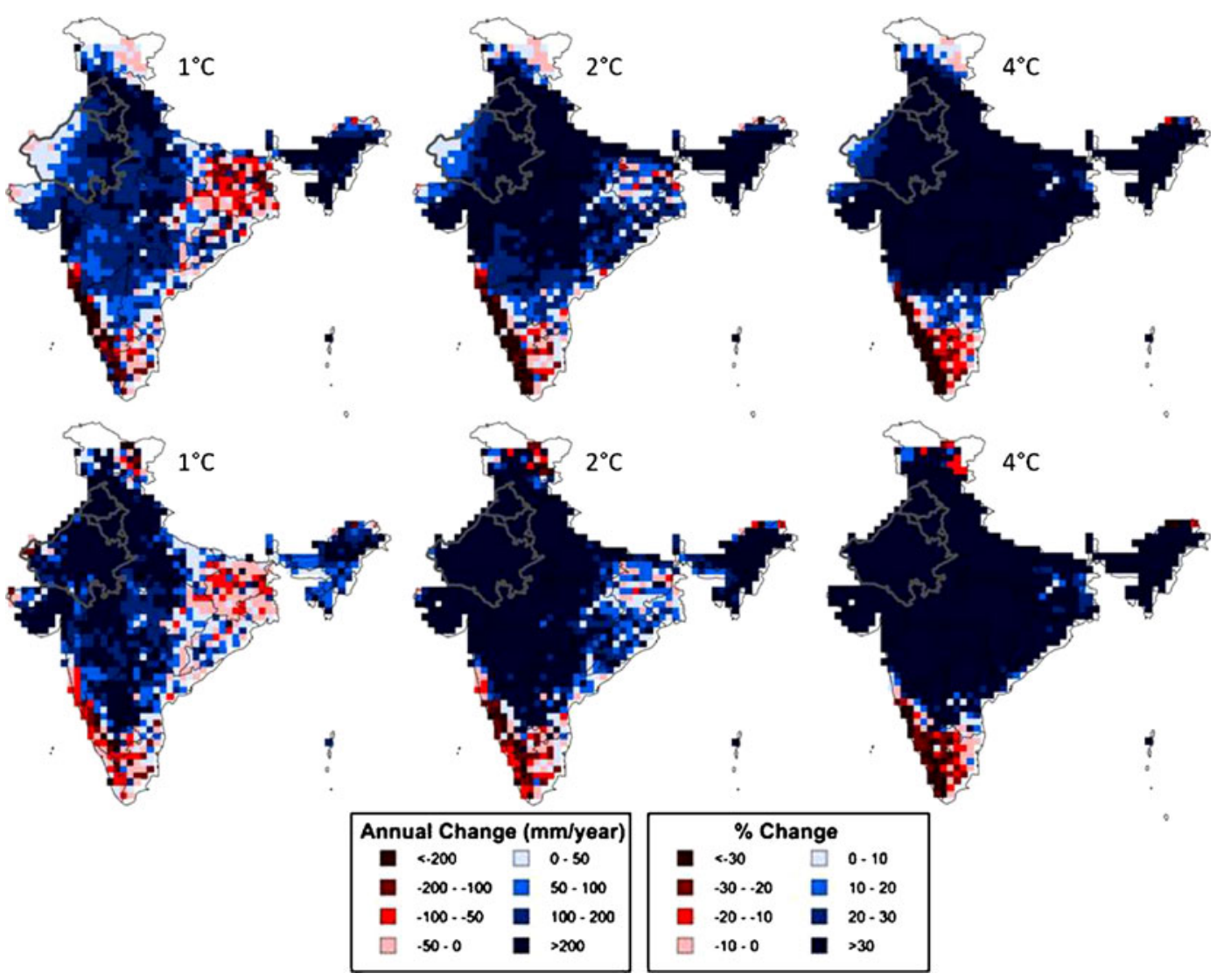

Figure 9. Future absolute (mm/year; upper) and relative (\%; lower) change in runoff in India for $1^{\circ}, 2^{\circ}$ and $4^{\circ} \mathrm{C}$ climate change (scaled to 2050) for 2070-2099 compared to 1961-1990.

runoff (e.g., Singh and Kumar 1997; Singh and Bengtsson 2003). Thus, more work is required to

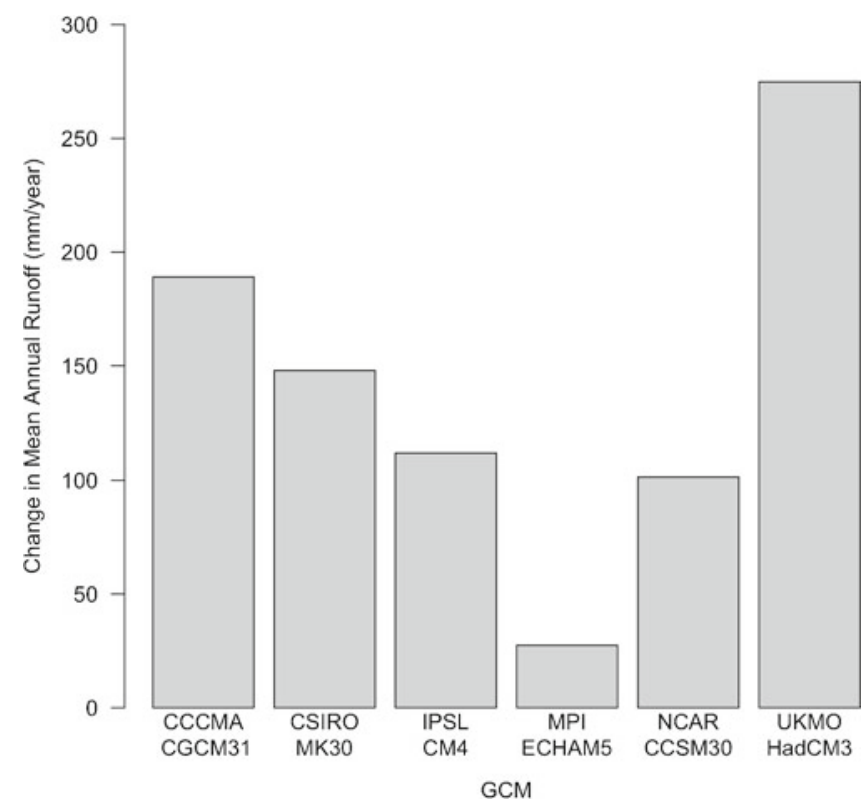

Figure 10. Change in mean annual runoff (mm/year) for north-west India as simulated by six GCMs for 2070-2099 relative to $1961-1990$ for $2^{\circ} \mathrm{C}$ (scaled to 2050) mean global climate change. address how demographic changes and associated water demands may evolve with respect to intraannual changes to runoff generation in the region.

\section{Conclusion}

The LPX DGVM has been used to simulate present and future runoff in tandem with GRACE satellite retrievals of recent groundwater depletion rates in north-west India. In spite of slight increases in runoff during 2002-2006, groundwater is shown to be extracted at an unsustainable rate. Given these opposing trend directions and to gain holistic insights into hydrological processes, it is concluded that surface and groundwater resources in the region should also be studied. This research consequently advocates the inclusion of groundwater modelling into DGVMs, in order to provide better-informed water resource assessments.

Considerable increases in runoff are projected across much of India for 2070-2099 using six GCMs; the magnitudes of these changes are temperature and model-dependent. For a given rise in temperature $\left(2^{\circ} \mathrm{C}\right.$ in this case), runoff distribution and magnitude are shown to be highly correlated 
Table 2. Number of years for which the future (2070-2099) changes in mean annual runoff in northwest India can support additional groundwater resources at the 2002-2008 rate of extraction under various magnitudes of climate change. Climate change scenarios are scaled to 2050.

\begin{tabular}{lcccc}
\hline & $\begin{array}{c}\mathrm{UKMO} \\
\mathrm{HadCM} 3\end{array} 1^{\circ} \mathrm{C}$ & $\begin{array}{c}\mathrm{UKMO} \\
\operatorname{HadCM} 32{ }^{\circ} \mathrm{C}\end{array}$ & $\begin{array}{c}\mathrm{UKMO} \\
\operatorname{HadCM} 3\end{array}{ }^{\circ} \mathrm{C}$ & $\begin{array}{c}\text { Mean of six GCMs } \\
\text { for } 2{ }^{\circ} \mathrm{C} \text { change }\end{array}$ \\
\hline $\begin{array}{l}\text { Mean change in } \\
\text { runoff (mm/year) }\end{array}$ & 139 & 275 & 476 & $189 \pm 247$ \\
$\begin{array}{l}\text { Years of additional } \\
\text { groundwater supply }\end{array}$ & $3.5 \pm 0.7$ & $6.9 \pm 1.4$ & $11.9 \pm 2.4$ & $4.7 \pm 0.9$ \\
$\begin{array}{l}\text { at 2002-2008 } \\
\text { extraction rate }\end{array}$ & & & & \\
\hline
\end{tabular}

with precipitation change. North-west India is simulated to undergo among the largest increases in future runoff throughout the country (mean change of $189 \mathrm{~mm} /$ year for $2^{\circ} \mathrm{C}$ climate change). Increasing temperatures are shown to induce greater magnitudes of future runoff in this region. However, this is likely to be tempered by further population growth and the potential of increasingly seasonal distributions of runoff. Since the ullage of the regional groundwater reservoir is unknown, this places a significant constraint on the ability to assess storage capacity or exhaustion thresholds in this study. Yet, it is shown that the current rate of groundwater depletion in this case is potentially unsustainable relative to the simulated increases in runoff, and enhanced runoff generation induced by climate change is only enough to moderately extend the longevity of the groundwater resource under current rates of extraction. Subsequent attention might be thus directed to improving the understanding of groundwater storage fluxes in the region and further developing local water management strategies.

\section{Acknowledgements}

S J Murray is the beneficiary of a doctoral grant from the AXA Research Fund. The author is grateful to M Rodell for provision of GRACE data, P N Foster for technical assistance regarding LPX and I M Watson for useful discussion concerning project direction.

\section{References}

Amarasinghe U A, Shah T, Turral H and Anand B K 2007 India's water future to 2025-2050: business-as-usual scenario and deviations; International Water Management Institute Research Report 123, International Water Management Institute, Colombo, Sri Lanka, 47p.

Chattopadhyay N and Hulme M 1997 Evaporation and potential evapotranspiration in India under conditions of recent and future climate change; Agric. Forest Meteorol. 87(1) $55-73$.
Central Ground Water Board 2006 Dynamic Ground Water Resources of India (as on March 2004), Indian Ministry of Water Resources, Government of India, Faridabad, India, $126 \mathrm{p}$.

Cleveland W S 1979 Robust locally weighted regression and smoothing scatterplots; J. Am. Sat. Assoc. 74(368) 829-836.

Etheridge D, Steele L, Langenfelds R, Francey R, Barnola J-M and Morgan V 1996 Natural and anthropogenic changes in atmospheric $\mathrm{CO}_{2}$ over the last 1000 years from air in Antarctic ice and firn; J. Geophys. Res. 101 D2 4115-4128.

Fekete B M, Vörösmarty C J and Grabs W 1999 Global, composite runoff fields based on observed river discharge and simulated water balances, GRDC Report 22, Global Runoff Data Center, Koblenz, Germany.

Fekete B M, Vörösmarty C J and Grabs W 2002 High resolution fields of global runoff combining observed river discharge and simulated water balances; Global Biogeochem. Cycles 16(3), doi: 10.1029/1999GB001254.

Flato G M, Boer G J, Lee W G, McFarlane N A, Ramsden D, Reader M C and Weaver A J 2000 The Canadian Centre for Climate Modelling and Analysis global coupled model and its climate; Clim. Dyn. 16 451-467.

Gerten D, Schaphoff S, Haberlandt U, Lucht W and Sitch S 2004 Terrestrial vegetation and water balance - hydrological evaluation of a dynamic global vegetation model; J. Hydrol. 286 249-270.

Gordon C, Cooper C, Senior C A, Banks H, Gregory J M, Johns T C, Mitchell J F B and Wood R A 2000 The simulation of SST, sea ice extents and ocean heat transports in a version of the Hadley Centre coupled model without flux adjustments; Clim. Dyn. 16(2-3) 147-168.

Gordon H B, Rotstayn L D, McGregor J L, Dix M R, Kowalczyk E A, O'Farrell S P, Waterman L J, Hirst A C, Wilson S G, Collier M A, Watterson I G and Elliott T I 2002 The CSIRO Mk3 Climate System Model; CSIRO Atmospheric Research Technical Paper No. 60, 130p.

Goyal R K 2004 Sensitivity of evapotranspiration to global warming: A case study of arid zone of Rajasthan (India); Agric. Water Manag. 69(1) 1-11.

Hickler T, Prentice I C, Smith B, Sykes M T and Zaehle S 2006 Implementing plant hydraulic architecture within the LPJ dynamic global vegetation model; Global Ecol. Biogeogr. 15 567-577.

Hobbins M T, Ramírez J A and Brown T C 2001 The complementary relationship in estimation of regional evapotranspiration: An enhanced advection-aridity model; Water Resour. Res. 37 1389-1403.

IPCC 2001 Appendix II - SRES Tables; In: Climate Change 2001: The Scientific Basis. Contribution of Working Group I to the Third Assessment Report of the Intergovernmental Panel on Climate Change (eds) Houghton J T, 
Ding Y, Griggs D J, Noguer M, van der Linden P J, Dai X, Maskell $\mathrm{K}$ and Johnson C A (Cambridge and New York: Cambridge University Press), 881p.

Israil M, Al-Hadithi M, Singhal D C and Kumar B 2006 Groundwater-recharge estimation using a surface electrical resistivity method in the Himalayan foothill region, India; Hydrogeol. J. 14(1-2) 44-50.

Jain S K, Agarwal P K and Singh V P 2007 Hydrology and water resources of India (Dordrecht, Netherlands: Springer), 1258p.

Jalota S K and Arora V K 2002 Model-based assessment of water balance components under different cropping systems in north-west India; Agric. Water Manag. 57(1) 75-87.

Kiehl J T, Hack J J, Bonan G B, Boville B A, Williamson D L and Rasch P J 1998 The national center for atmospheric research community climate model: CCM3; J. Clim. 11 1131-1149.

Klein Goldewijk K, van Drecht G and Bouwman A 2007 Mapping contemporary global cropland and grassland distributions on a $5 \times 5$ min resolution; J. Land Use Sci. 2(3) 167-190.

Kumar R, Singh R D and Sharma K D 2005 Water resources of India; Curr. Sci. 89 794-811.

Mall R K, Gupta A, Singh R, Singh R S and Rathore L S 2006 Water resources and climate change: An Indian perspective; Curr. Sci. 90(12) 1610-1626.

Marti O, Braconnot P, Bellier J, Benshila R, Bony S, Brockmann P, Cadule P, Caubel A, Denvil S, Dufresne J-L, Fairhead L, Filiberti M-A, Foujols M-A, Fichefet T, Friedlingstein P, Goosse H, Grandpeix J-Y, Hourdin F, Krinner G, Lévy C, Madec G, Musat I, de Noblet N, Polcher J and Talandier C 2005 The new IPSL climate system model: IPSL-CM4, Technical Report No 26, Institut Pierre Simon Laplace des Sciences de l'Environment Global: IPSL, Case 101, Paris, France.

Mitchell T D and Jones P D 2005 An improved method of constructing a database of monthly climate observations and associated high-resolution grids; Int. J. Climatol. 25(6) 693-712.

Mitchell T D and Osborn T J 2005 ClimGen: A flexible tool for generating monthly climate data sets and scenarios; Tyndall Centre for Climate Change Research Working Paper (in preparation).

Monteith J L 1995 Accommodation between transpiring vegetation and the convective boundary layer; J. Hydrol. 166 251-263.

Murray S J 2013 Trends in 20th century global rainfall interception as simulated by a dynamic global vegetation model: Implications for global water resources; Ecohydrology, doi: 10.1002/eco.1325.

Murray S J, Foster P N and Prentice I C 2011 Evaluation of continental hydrology as simulated by the Land-surface Processes and eXchanges dynamic global vegetation model; Hydrol. Earth Syst. Sci. 15 91-105.

Murray S J, Watson I M and Prentice I C 2013 The use of dynamic global vegetation models for simulating large scale hydrology; Progr. Phys. Geogr., doi: 10.1177/ 0309133312460072.

Murray S J, Foster P N and Prentice I C 2012 Future global water resources with respect to climate change and population dynamics; J. Hydrol., doi: 10.1016/j.jhydrol. 2012.02.044.

Naik P and Awasthi A 2003 Groundwater resources assessment of the Koyna river basin, India; Hydrogeol. J. 11(5) $582-594$.

Prentice I C, Kelley D I, Foster P N, Friedlingstein P, Harrison S P and Bartlein P J 2011 Modeling fire and the terrestrial carbon balance; Global Biogeochem. Cycles $\mathbf{2 5}$ GB3005, doi: 10.1029/2010GB003906.
Priestley C H B and Taylor R J 1972 On the assessment of surface heat flux and evaporation using large-scale parameters; Mon. Weather Rev. 100 81-92.

Rangarajan R and Athavale R N 2000 Annual replenishable ground water potential of India - an estimate based on injected tritium studies; J. Hydrol. 234(1-2) 38-53.

Rodell M, Houser P R, Jambor U, Gottschalk J, Mitchell K, Meng C-J, Arsenault K, Cosgrove B, Radacovich J, Bosilovich M, Entin J K, Walker J P, Lohmann D and Toll D 2004 The global land data assimilation system; Bull. Am. Meteor. Soc. 85 381-394.

Rodell M, Velicogna I and Famiglietti J S 2009 Satellitebased estimates of groundwater depletion in India; Nature 460(7258) 999-1002.

Roeckner E, Bäuml G, Bonaventura L, Brokopt R, Esch M, Marco G, Stefan H, Ingo K, Luis K, Elisa M, Andreas R, Ulrich S, Uwe S and Tompkins A 2003 The atmospheric general circulation model ECHAM 5. Part I: Model description; Technical Report 349, Max Planck Institute for Meteorology, Hamburg.

Sharda V N, Kurothe R S, Sena D R, Pande V C and Tiwari S P 2006 Estimation of groundwater recharge from water storage structures in a semi-arid climate of India; J. Hydrol. 329(1-2) 224-243.

Singh P and Kumar N 1997 Impact assessment of climate change on the hydrological response of a snow and glacier melt runoff dominated Himalayan river; J. Hydrol. 193 316-350.

Singh P and Bengtsson L 2003 Effect of warmer climate on the depletion of snow-covered area in the Satluj basin in the western Himalayan region; Hydrol. Sci. J. 48(3) $413-425$.

Sitch S, Smith B, Prentice I C, Arneth A, Bondeau A, Cramer W, Kaplan J O, Levis S, Lucht W, Sykes T M, Thonicke K and Venevsky S 2003 Evaluation of ecosystem dynamics, plant geography and terrestrial carbon cycling in the LPJ dynamic global vegetation model; Global Change Biol. 9 161-185.

Strassberg G, Scanlon B R and Chambers D 2009 Evaluation of groundwater storage monitoring with the GRACE satellite: Case study of the High Plains aquifer, central United States; Water Resour. Res. 45 W05410, doi: 10.1029/2008WR006892.

Sukhija B S, Nagabhushaman P and Reddy D V 1996 Groundwater recharge in semi-arid regions of India: An overview of results obtained using tracers; Hydrogeol. J. 4(3) 50-71.

Swenson S and Wahr J 2006 Post-processing removal of correlated errors in GRACE data; Geophys. Res. Lett. 33 L08402, doi: 10.1029/2005GL025285.

Syed T H, Famiglietti J S, Chambers D P, Willis J K and Hilburn K 2010 Satellite-based global-ocean mass of interannual variability and emerging continental freshwater discharge; Proc. Nat. Acad. Sci. 107(42) 17,916-17,921.

Tapley B D, Bettadpur S, Ries J C, Thompson P F and Watkins M M 2004 GRACE measurements of mass variability in the Earth system; Science 305 503-505.

Timsina J, Godwin D, Humphreys E, Yadvinder-Singh, Bijay-Singh, Kukal S S and Smith D 2008 Evaluation of options for increasing yield and water productivity of wheat in Punjab, India using the DSSAT-CSMCERES-Wheat model; Agric. Water Manag. 95(9) 1099-1110.

Tiwari V M, Wahr J and Swenson S 2009 Dwindling groundwater resources in northern India, from satellite gravity observations; Geophys. Res. Lett. 36 L18401, doi: 10.1029/2009GL039401.

Ukkola A M and Murray S J 2013 Hydrological evaluation of the LPX dynamic global vegetation model for small river 
catchments in the UK, Hydrol. Process. (accepted for publication).

Wada Y, van Beek L P H, van Kempen C M, Reckman J W T M, Vasak S and Bierkens M F P 2010 Global depletion of groundwater resources; Geophys. Res. Lett. 37 L20402, doi: 10.1029/2010GL044571.

Wagner W, Scipal K, Pathe C, Gerten D, Lucht W and Rudolf B 2003 Evaluation of the agreement between the first global remotely sensed soil moisture data with model and precipitation data; J. Geophys. Res. 108 D19, 4611, doi: 10.1029/2003JD003663.
Woodward F I and Cramer W 1996 Plant functional types and climatic changes: introduction; J. Veg. Sci. 7(3) 306-308.

Yeh P J-F, Swenson S C, Famiglietti J S and Rodell M 2006 Remote sensing of groundwater storage changes in Illinois using the Gravity Recovery and Climate Experiment (GRACE); Water Resour. Res. 42 W12203, doi: 10.1029/2006WR005374.

Zobler L 1986 A world soil file for global climate modelling; NASA Technical Memorandum 87802, NASA/GISS, New York, USA, 32p. 